they appear to have on the whole a wider distribution than most coastal fishes, still seem to be limited mainly by temperature. In the case of the abyssal forms, the contour of the sea floor may play an important part in limiting their range, and it may be noted that the submarine ridge running from Scotland to Iceland and Greenland, less than 1,000 metres in depth, is the northern limit of the Macruridæ, the most characteristic family of bottom-living oceanic fishes. Our knowledge of the distribution of the bathypelagic fishes is still very incomplete, but it may be said that a number of them have a cosmopolitan range and that recent investigations have tended to add greatly to this number. Some of them are capable of extensive vertical migrations, and it may be that they are able to negotiate barriers which would be effective in limiting the spread of coastal fishes.

Dr. Stanley Kemp emphasized the importance to the general question of marine distribution of the comparative stability of species in the sea, and instanced the occurrence of identical species of fish and crustacea on both sides of the Isthmus of Panama in support of the view that species can remain identical over a long period of time. He thought that this would account for some of the instances of bipolarity, and mentioned a Euphausian common in the north and south but absent over a large stretch of the middle Atlantic. If species have remained unaltered for long periods of time, any arguments which base distribution upon existing ocean currents must be fallacious.

As an example of the adaptation of a planktonic fauna to hydrographical conditions Dr. Kemp mentioned the work of Mackintosh, who had shown that plankton at the time it approaches the Antarctic Convergence sinks to a deeper level and in this way is carried back to its proper habitat in the Antarctic. The deep-water prawns of the genus Acanthephyra, which are abundant in tropical and temperate parts of the oceans, have recently been investigated in detail, and have been found to have become differentiated in the various oceans. The species are separated by quite trivial characters (the number of spines on the telson), which are, however, astonishingly constant. One species in the Atlantic shows a widely discontinuous distribution.

Dr. G. P. Bidder wondered whether the length of the larval life was really so important a factor in the dispersal of sponges, and suggested that in the case of calcareous sponges these might be carried to new localities on the bottoms of ships. He pointed out that the largest and finest specimens found at Naples and Plymouth were collected from vessels anchored in harbour for a month or so.

Prof. W. Garstang suggested that an interesting approach to the problem as far as pelagic animals are concerned would be to tabulate the differences in distribution of those forms with large and small larval stages respectively.

\title{
OBITUARIES
}

\section{Prof. Jules Schokalsky}

$\mathrm{T}$ HE distinguished Russian geographer Prof. Jules Schokalsky died in Leningrad on March 26 at the age of eighty-four. He was widely known throughout Europe and America, where he made many friends at international scientific gatherings. As a boy he lived much in the country and acquired a love of Nature by his comradeship with a son of the poet Pushkin, and this æsthetic sentiment opened the way to serious scientific study. He led a life of ceaseless activity from the time he entered the Naval School at St. Petersburg in 1874 until his death, and for forty-five years I have had the privilege of enjoying his helpful friendship. Even the shock of the Russian revolution of 1917 did not check the continuity of his work; to him science was superior to politics. $\mathrm{He}$ continued under the Soviet system in Leningrad to give full expression to the enthusiasm for oceanography and cartography which had animated him during half a century under the Empire.

Schokalsky studied at the Naval School in St. Petersburg, and in 1877 he went to sea as a midshipman in the Imperial Navy. After two years he turned to shore work connected with naval research and education, spending three years at the National Physical Observatory under the great meteorologist, Dr. H. Wild. After this he joined the teaching staff at the Naval Academy and was professor and then emeritus professor of physical geography, meteorology and oceanography from 1910 until 1930. For a time he was librarian of the Central Library of the Russian Admiralty, and he ended his academic career and his life as professor in the University of Leningrad. He found time for innumerable honorary appointments, culminating in the presidency of the Imperial Russian Geographical Society, which he held for many years, and on his retirement was appointed honorary president of the same Society under the U.S.S.R.

He was a tireless writer with nearly five hundred entries of publications under his name, many of them, of course, being official reports, summaries and criticisms. His most important book was the "Treatise on Oceanography", in Russian, published in 1917. This is a work of originality and distinction, showing much ingenuity in the design of illustrative 
diagrams. He produced or edited with valuable introductions many atlases of the physical features of Russia. He paid special attention to hypometrical work and completed a map of the altitudes of European Russia in six sheets on the scale of $1: 2,500,000$.

Schokalsky planned and carried out an important series of researches on the temperature regime of Lake Ladoga during the years 1897-1902. The supreme contribution which he made to oceanography was the organization of physical investigations in the Black Sea. This was carried out under his personal leadership during 1924-27 in conditions of much difficulty and even privation. The result was to throw new light on the remarkable physical and chemical changes proceeding in the lifeless deep water of this anomalous land-locked basin. A special feature of the work was the collection for the first time of very long cores of deep-sea deposits; the length of these ranged up to one and a half metres.

Prof. Schokalsky had much charm of manner and great kindness of heart combined with dignity and a fine sense of honour. He made himself welcome wherever he went despite the deafness which latterly grew upon him. His later years were cheered by the companionship of a devoted daughter, herself distinguished in the modern science of soil analysis. Hugh Robert Mill.

\section{Sir James Mackenna, C.I.E.}

Sir James Mackenna, who died on April 3, aged sixty-seven, belonged to the small band of members of the Indian Civil Service who, though not scientific workers themselves, employed their long service in India in encouraging the application of science to the solution of the agricultural problems of the country. I first met him in 1904, when he had been some ten years in Burma and was already recognized as one of the most successful directors of agriculture of his time. Even then he showed those qualities which distinguished him throughout his career-a thorough grasp of the problems of rural development, a strong belief that agricultural research was likely to lead to a great improvement in Indian crops and stock, and a faculty for getting things done. From this time on, his work as a member of the Indian Civil Service was chiefly concerned with agricultural development in Burma, until he was appointed agricultural adviser to the Government of India in 1916.

Mackenna's work in the last-named position was of outstanding importance. On his recommendation, two committees were appointed to consider, respectively, cotton and sugar production in India in all their aspects, and the results on the development of these industries have been very great. The former committee, among other things, recommended the establishment of the first self-supporting research organization for a purely Indian industry, and the existence of the Indian Central Cotton Committee, a permanent body with ample funds which controls research on cotton problems throughout India, has been very much of a landmark in the later agricultural history in India. Similar bodies have more recently been formed in connexion with other industries, but the idea came from the Mackenna Committee, and was probably the idea of Mackenna himself.

In 1920 he went back to Burma, and for the next five years he was the life and soul of many development projects which date from that period. After retirement to England in 1925, he was almost at once appointed a member of the Royal Commission on Agriculture in India, and toured the country again between 1926 and 1928. The chief result of that Commission has been the establishment of the Imperial Council of Agricultural Research and it is impossible not to see Mackenna's hand in a good deal of the organization of that Council, which has become the centre of scientific activity in connexion with Indian agriculture.

After his final retirement from India, Mackenna continued his interest in scientific work, especially as concerns Indian agriculture. He remained active to the end and was still the same inspiring personality as he had been in his prime. His principal claim to scientific recognition is that he never ceased to use the strong influence which he could exert, for the encouragement of research, while he had the faculty of inspiring those who were entrusted with the carrying out of the work which he had in mind. H. H. MaNN.

\section{Sir Gilbert Barling, Bart.}

Sir Grubert Barling, Bart., died suddenly of heart failure at his home in Edgbaston on April 27, within three days of his eighty-fifth birthday. Sir Gilbert was the second vice-chancellor (afterwards prochancellor) of the University of Birmingham which he served for twenty years, having succeeded Charles Gabriel Beale in that office in 1913. From 1913 until 1933 he gave invaluable service to the University, which derived great benefit from his forceful personality and his unremitting personal devotion to its interests. Himself actively interested in outdoor sports, he did much to encourage the athletic side of university education. At the annual meeting of the Birmingham United Hospital, only a week before his death, Sir Gilbert was presented with an address of congratulation on completing sixty years of strenuous service to the hospitals of Birmingham.

WE regret to announce the following deaths:

Mr. Owen Cattell, director of the annual exhibition of the American Association, assistant to the editor of Science, on March 26, aged forty-two.

Prof. Alexandre Desgrez, emeritus professor of medical chemistry in the University of Paris, aged seventy-six.

Captain E. E. M. Joyce, the well-known Antarctic explorer, on April 2, aged sixty-five.

Mr. G. W. Partridge, a pioneer of electricity supply, on May 3. 